\title{
Immunotherapy in HIV infection; current and future challenges
}

\author{
Yves Lévy \\ From $16^{\text {th }}$ International Symposium on HIV and Emerging Infectious Diseases \\ Marseille, France. 24-26 March 2010
}

Administration of HAART has resulted in significant improvements in the survival of HIV-infected patients. However, despite now reaching a point where we can achieve durable, maximal suppression of plasma viral load in most of our HAART-treated patients, nonAIDS-related morbidity and mortality among these patients remain a concern. Conditions typical of aging, such as cardiovascular disease and cancer, are seen at a higher rate in HIV-infected patients compared to the general population, potentially because the ability of HAART to restore immunocompetence appears incomplete-even in patients who have long-term undetectable HIV-1 RNA.

New insights into the pathogenesis of HIV-1 infection highlight several new and promising areas of investigation for immune-based therapies, including strategies that target $\mathrm{T}$-cell homeostasis and immune activation, as well those targeted at restoring immune responses directed against HIV.

The rationale behind the investigation of a of cytokines such as IL-2 and IL-7 as adjunctive therapies to antiretroviral treatment is to improve the restoration of the immune system and improve HIV-directed immune responses. Among cytokines, IL-2, was extensively studied in several phase II and two large phase III studies. Results from these studies showed that IL-2 increases signficantly CD4 counts in the long term. However, this biological effect did not translate into clinical benefit. These results raise several questions about the functionality of IL-2 expanded CD4 $\mathrm{T}$ cells that will be discussed.

The potential interest of IL-7 is based on its crucial role on $\mathrm{T}$ cell homeostasis both in thymic output and peripheral $\mathrm{T}$ proliferation and survival. This new promising cytokine is currently under evaluation is several

\footnotetext{
Service d'Immunologie Clinique, INSERM U955, CHU Henri Mondor, Faculté
} de médecine, Université Paris 12, Créteil, France
I/II clinical trials in chronically HIV-infected patients with low level of immune restoration despite controlled viral load. Results from these studies will be presented and discussed.

Published: 11 May 2010

doi:10.1186/1742-4690-7-S1-I13

Cite this article as: Lévy: Immunotherapy in HIV infection; current and future challenges. Retrovirology 2010 7(Suppl 1):113.

Submit your next manuscript to BioMed Central and take full advantage of:

- Convenient online submission

- Thorough peer review

- No space constraints or color figure charges

- Immediate publication on acceptance

- Inclusion in PubMed, CAS, Scopus and Google Scholar

- Research which is freely available for redistribution

Submit your manuscript at www.biomedcentral.com/submit 